\title{
A new species of Temnocephala Blanchard (Platyhelminthes, Temnocephalida) ectosymbiont on creeping water bugs, Cryphocricos granulosus De Carlo (Hemiptera, Naucoridae) from southern Brazil ${ }^{1}$
}

\author{
José F. R. Amato ${ }^{2}$; Samantha A. Seixas ${ }^{2} \&$ Suzana B. Amato ${ }^{2}$ \\ ${ }^{1}$ Contribution number 519 of the Departamento de Zoologia, Universidade Federal do Rio Grande do Sul. \\ ${ }^{2}$ Departamento de Zoologia, Instituto de Biociências, Universidade Federal do Rio Grande do Sul. Caixa Postal 15014, 91501-970 \\ Porto Alegre, Rio Grande do Sul, Brasil. E-mail: jfamato@terra.com.br; samantha_bio@yahoo.com.br; sbamato@ufrgs.br
}

\begin{abstract}
Temnocephala minutocirrus sp. nov., an ectosymbiont on Cryphocricos granulosus De Carlo, 1967, is described from the State of Rio Grande do Sul, southern Brazil. One hundred and nine naucorids were examined, of which $36(33 \%)$ were positive for this species of Temnocephala Blanchard, 1849. In one sample of 94 creeping water bugs, $49(52 \%)$ were $4^{\text {th }}$ instar nymphs, $6 \%$ of which were infested; $45(48 \%)$ were adults, either brachypterous ( 40 with 18 males and 22 females) or macropterous ( 5 with 1 male and 4 females), $67 \%$ of which were infested (29\% males and $38 \%$ females). Temnocephalan eggs were found both ventrally and dorsally: fixed on coxae, trochanters, and along the sternum between fore middle, and hind pairs of legs; basal of the abdominal area; and on the scutellum, clavus, and hemelytra. Juvenile and adult temnocephalans were always devoid of body pigmentation, and were found living on the ventral body surface, preferably over the sternum, between the middle and hind pairs of legs. The most distinctive features of this new species are: 1) unusually short cirrus, slightly curved, with introvert corresponding to $37 \%$ of its total length; 2) dorsolateral 'excretory' syncytial epidermal plates, elliptic, with excretory pore relatively equatorial, closer to inner limit of each plate; 3) two pairs of large disc gland cells (paranephrocytes?) located centrally, just ahead of testes; 4 ) testes relatively large, but unequal in size, anterior pair smaller, always in the same zone, those of the same side, partially superposed; and (5) vagina with weak muscular wall and without muscular sphincters.
\end{abstract}

KEY WORDS. Ectocommensals; Neotropical Region; Rio Grande do Sul; South America; taxonomy.

\begin{abstract}
RESUMO. Nova espécie de Temnocephala Blanchard (Platyhelminthes, Temnocephalida) ectosimbionte sobre naucorídeos, Cryphocricos granulosus De Carlo (Hemiptera, Naucoridae) da Região Sul do Brasil. Temnocephala minutocirrus sp. nov., ectosimbionte sobre Cryphocricos granulosus De Carlo, 1967, é descrita para o Estado do Rio Grande do Sul. Cento e nove naucorídeos foram examinados, dos quais 36 (33\%) estavam positivos para esta espécie do gênero Temnocephala Blanchard, 1849. Em uma amostra de 94 hemípteros, 49 (52\%) eram ninfas de $4^{\circ}$ instar, das quais, $6 \%$ estavam infestadas; 45 (48\%) eram adultos, braquípteros 40 (18 machos e 22 fêmeas) ou macrópteros 5 ( 1 macho e 4 fêmeas), $67 \%$ dos quais estavam infestados ( $29 \%$ machos e $38 \%$ fêmeas), para esta espécie de temnocefalídeo. Ovos dos temnocefalídeos estavam fixados na face ventral do hemíptero, sobre as coxas, trocânteres e esterno, entre o primeiro, segundo e terceiro pares de pernas e na face dorsal, sobre o escutelo, clavo e hemiélitros. Temnocefalídeos juvenis e adultos sempre se apresentaram sem pigmentação corporal. Os caracteres mais distintivos da nova espécie são: 1) cirro muito curto, levemente curvo, com o 'introvert' correspondendo a $37 \%$ do comprimento total; 2) placas dorsolaterais, sinciciais 'excretoras' elípticas, com poro excretor equatorial, próximo do limite interno da placa; 3 ) dois pares de 'grandes glândulas do disco' (paranefrócitos?) centrais, imediatamente à frente dos testículos; 4) testículos relativamente grandes, mas desiguais em tamanho, par anterior menor, sempre na mesma zona, aqueles do mesmo lado, parcialmente sobrepostos; e 5) vagina com parede muscular fracamente desenvolvida e sem esfíncteres musculares.

PALAVRAS-CHAVE. América do Sul; ectocomensais; Região Neotropical; Rio Grande do Sul; taxonomia.
\end{abstract}

Temnocephalans identified as Temnocephala lanei Pereira $\&$ Cuocolo, 1941, were collected for the first time on creeping water bugs and water scorpions by Vianna \& DE Melo (2002). The authors found these temnocephalans on several species of Limnocoris Stål, 1860 (Naucoridae Leach, 1815) and on a species of Ranatra Fabricius, 1790 (Nepidae Latreille, 1802) collected from 
streams of Serra do Cipó, Municipality of Santana do Riacho $\left(19^{\circ} 15^{\prime} \mathrm{S}, 043^{\circ} 32^{\prime} \mathrm{W}\right)$, and Retiro das Pedras (20² $\left.04^{\prime} \mathrm{S}, 044^{\circ} 00^{\prime} \mathrm{W}\right)$, Municipality of Brumadinho, State of Minas Gerais, Brazil.

Temnocephala lanei was originally described as an ectosymbiont of an undetermined species of Trichodactylus Latreille, 1828 found at Fazenda Poço Grande, Municipality of Juquiá, State of São Paulo (Pereira \& Cuocolo 1941). Damborenea \& Cannon (2001) while reviewing the Neotropical species of Temnocephala Blanchard, 1849, listed T. lanei, but did not collect specimens nor present drawings of the cirrus and the dorsolateral, epidermal 'excretory' syncytial plates (DLSPs).

The only complete study (description and illustrations) of a species of Temnocephala from aquatic Heteroptera known to date is that of Temnocephala curvicirri Amato \& Amato, 2005, ectosymbiont on belostomatids in the State of Rio Grande do Sul, southern Brazil (Амато \& AмAтo 2005). The present paper adds a complete study on the second species of Temnocephala ectosymbiont on aquatic heteropterans.

\section{MATERIAL AND METHODS}

One hundred and nine creeping water bugs were collected from 2002 to 2006, using dip nets, large sand sieves and/or a Surber sampler, and transported live to the Laboratório de Helmintologia, Universidade Federal do Rio Grande do Sul (UFRGS). Live temnocephalans were obtained from hosts collected from Arroio Forqueta ( $29^{\circ} 32^{\prime} 19^{\prime \prime}$ S, 050 $\left.14^{\prime} 47^{\prime \prime} \mathrm{W}\right)$, Arroio Garapiá (29030'23"S, $\left.050^{\circ} 14^{\prime} 38^{\prime \prime} \mathrm{W}\right)$, both belonging to the Rio Maquiné Basin, District of Barra do Ouro, Municipality of Maquiné; and Rio da Divisa (28 38'17"S, 04957'46”W), Municipality of São José dos Ausentes, Rio Pelotas Basin; all in the State of Rio Grande do Sul, Brazil. Both areas are included in the Atlantic Rain Forest (Brazilian Atlantic Forest Biome).

Some helminths taken from live hosts were fixed and prepared for internal morphometry according to АмAто et al. (2005). To preserve eyespot pigmentation, body shape, and for scanning electron microscope (SEM) studies, some specimens were flooded with hot formalin (HF) (АмAто et al. 2006). Morphology of dorsolateral 'excretory' syncytial epidermal plates (DLSPs) was studied in specimens fixed with silver nitrate (SN) (Romeis 1968, Joffe et al. 1995) or observed with SEM (АмAто et al. 2005). Cirrus morphology was studied after microdissection and mounting in de Faure's (deF) medium (CANNON \& Sewell 1995); cirrus measurements follow Амато et al. (2005). Distribution of rhabditogenic and disc glands was studied by clearing small juvenile specimens in lactophenol (Амато et al. 2005). Groups of unhatched eggs, removed from hosts by scrapping were dehydrated, cleared in cedar oil, and mounted in Canada balsam. The terminology to describe male reproductive structures follows Амато et al. (2006).

Photomacrographs of hosts were taken with a Zeiss Stemi SV-6 stereomicroscope (Figs 1-4). Photomicrographs were taken with a Zeiss Axiolab microscope with phase contrast (or just the phase contrast condenser), and/or Olympus BX50 micro- scope with Nomarski's differential interference contrast (DIC) prisms, and/or a Jeol (JSM-5800) SEM. Drawings were made with a drawing tube on a Nikon E-200 microscope. Measurements are in micrometers $(\mu \mathrm{m})$ unless otherwise indicated; ranges are followed by the arithmetic mean, the number of specimens measured for a given character (when different than 12 ), and the standard deviation values (between parentheses).

The holotype and some paratypes fixed in AFA, HF, and $\mathrm{SN}$, as well as slides containing individual cirri in deF and unhatched eggs, were deposited in the Coleção Helmintológica do Instituto Oswaldo Cruz (CHIOC), Rio de Janeiro, RJ, Brazil. Some naucorid hosts were deposited in the Colorado Entomological Institute, Engelwood, Colorado, USA, while others were deposited in the Coleção do Departamento de Zoologia, Laboratório de Entomologia Sistemática, UFRGS (DZRS/UFRGS). The remaining host specimens and temnocephalans are in the host and helminth collection of the Laboratório de Helmintologia (SBA), UFRGS, Porto Alegre, Rio Grande do Sul, Brazil.

\section{RESULTS \\ Temnocephala minutocirrus sp. nov. Figs 5-21}

Description. Based on 102 specimens collected; 36 adults, whole-mounted; 19 juveniles; 2 specimens mounted on stubs for SEM; 5 dissected cirri, mounted in deF; 6 mounted specimens, fixed in $\mathrm{SN} ; 12$ specimens measured, fixed in AFA under slight cover slip pressure.

External characteristics. Body (without tentacles) 5301461 (250, 249) long; 480-970 (723, 150) wide (Fig. 6); adhesive disk ventral, subterminal, pedunculate, $170-370(293,61)$ in diameter; live body pigmentation absent in juvenile and adult specimens (Fig. 8). Eyespots round, with red pigment in live specimens; pigment dissolving in specimens fixed in ethanol, but not in formalin. Epidermal mosaic with two dorsolateral, elliptical DLSPs (Figs 10 and 16-17), extending from basis of first and fifth tentacles, respectively; left plate 123-160 (140, $\mathrm{n}=3$, 19) long, 48-93 $(68, \mathrm{n}=3,23)$ wide; right plate $108-230$ $(158, \mathrm{n}=5,48)$ long, 58-155 $(85, \mathrm{n}=5,41)$ wide; relationship between length of DLSPs/total body length, without tentacles, 3.5: 1. Excretory pore (nephridiopore) near or a little below the equatorial line of the DLSPs and closer to the inner margin of each syncytial plate (Figs 10 and 16-17).

Alimentary system. Mouth surrounded by a small muscular sphincter, between first and second thirds of body; pharynx wider than long, 120-300 (188, 45) long, 200-350 (271, 48) wide, with a large sphincter; esophageal glands surrounding it at base; intestine saccular, with conspicuous septations in juveniles and adults; intestinal walls thick (Figs 7 and 11).

Excretory system. Excretory ampullae round, at level of mouth (Figs 11 and 12), generally directed outwards.

Glands. Rhabditogenic glands large, numerous, with a granular appearance, forming bunches (average of 20 cells), in lateral fields of the body, $28-55(41,10)$ in diameter, extending 

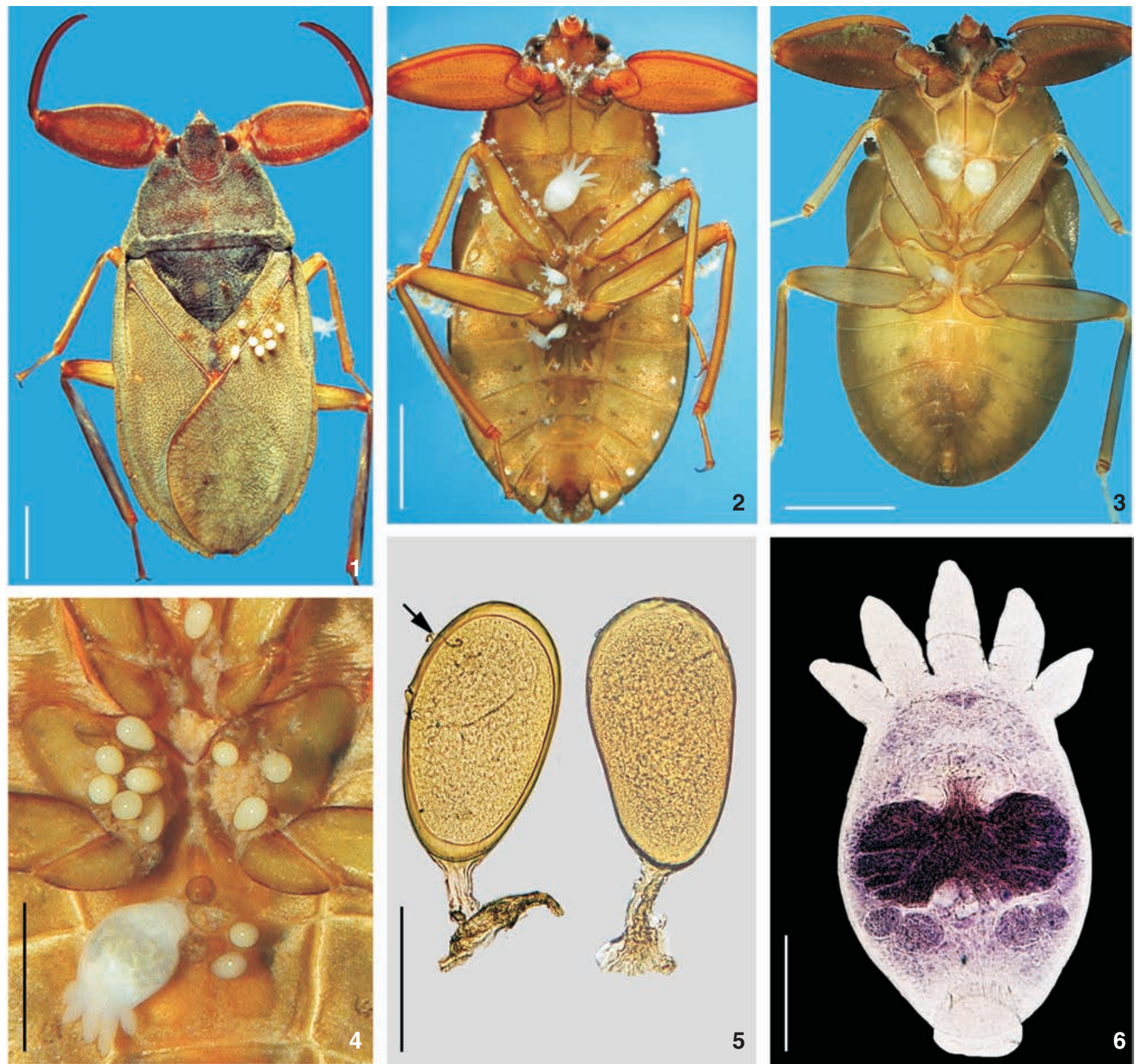

Figures 1-6. (1-4) Cryphocricus granulosus: (1) dorsal view of a macropterous male, showing hatched and unhatched eggs deposited on scutellum, clavus, and hemelytra, bar $=2 \mathrm{~mm}$; (2) ventral view of a macropterous female, showing the entire infrapopulation of temnocephalans on the ventral surface of body, bar $=2 \mathrm{~mm}$; (3) ventral view of a $4^{\text {th }}$ instar female nymph, showing several specimens of Temnocephala minutocirrus sp. nov., bar $=2 \mathrm{~mm}$; (4) higher magnification of coxae and trochanters of another host specimen, showing several hatched and unhatched eggs, as well as an adult specimen laying eggs, bar = $1 \mathrm{~mm}$; (5) two eggs of $T$. minutocirrus sp. nov., cleared in cedar oil, showing egg shape and sub-apical filament (arrow), bar $=200 \mu \mathrm{m}$; (6) Temnocephala minutocirrus sp. nov., adult (holotype), bar $=250 \mu \mathrm{m}$.

on the sides of the intestinal sac, with conspicuous ducts, best observed in juvenile specimens cleared in lactophenol, before complete development of vitellarium (Figs 9 and 11). Two groups of five Haswell's glands, showing little affinity with he- matoxylin, in front of the eyespots and the brain transverse band, diameter of the largest one $47-87(61, \mathrm{n}=11,12)$ (Fig. 12). Esophageal glands forming a collar between pharynx and intestinal sac. Disc glands between adhesive disc and genital 


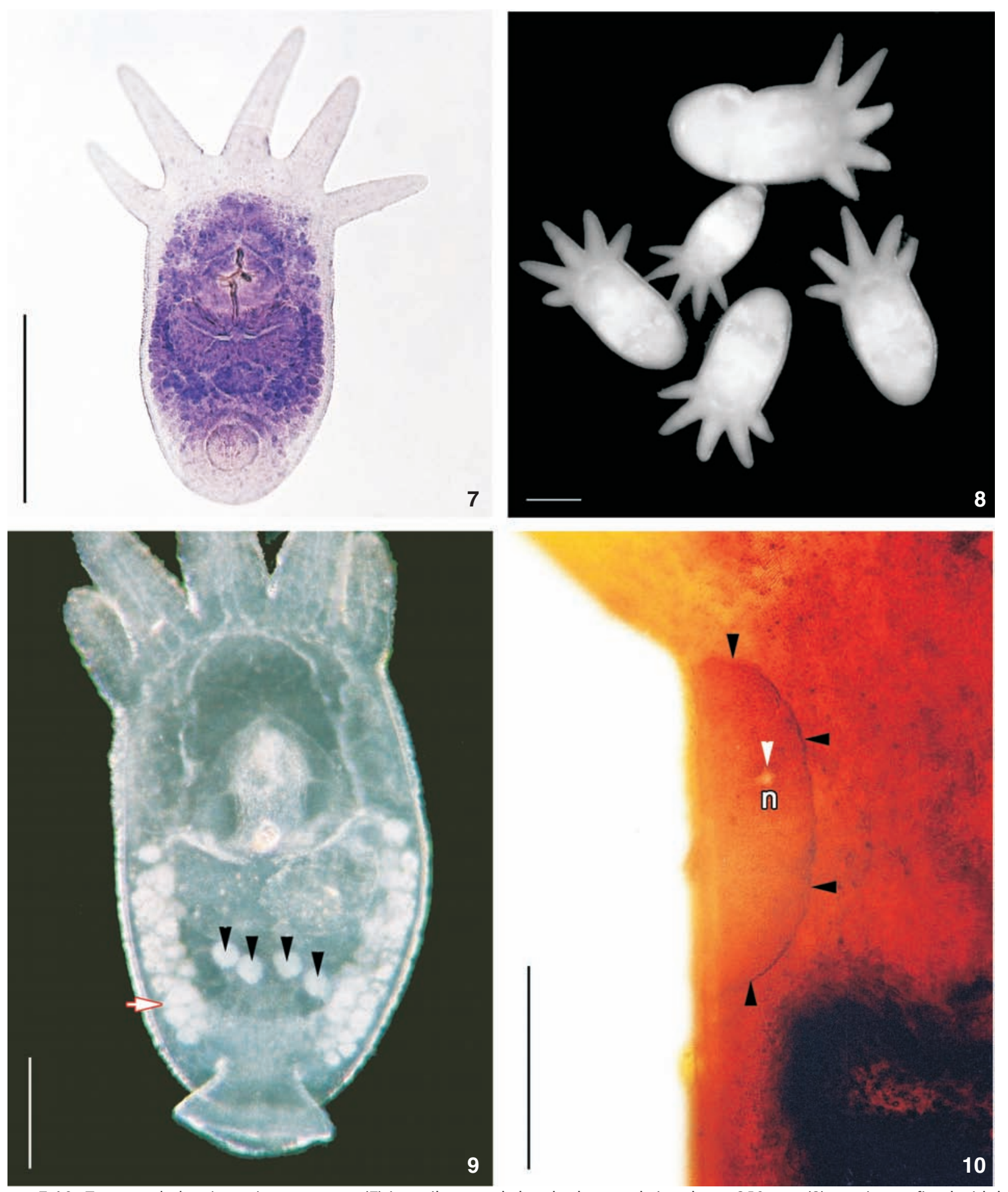

Figures 7-10. Temnocephala minutocirrus sp. nov.: (7) juvenile recently hatched, ventral view, bar $=250 \mu$ m; (8) specimens fixed with hot formalin, showing body shape, bar $=250 \mu \mathrm{m}$; (9) juvenile cleared in lactophenol showing rhabditogenic and disk glands (limit shown by white arrow) and the two pairs of large disc glands (paranephrocytes?) (black head arrows), a particular character of this species, bar $=100 \mu \mathrm{m}$; (10) adult fixed with silver nitrate, showing the elliptical, dorsolateral, left syncytial plate (limits indicated by black head arrows) and nephridiopore (n), bar $=100 \mu \mathrm{m}$.

Revista Brasileira de Zoologia 24 (4): 1043-1051, dezembro 2007 

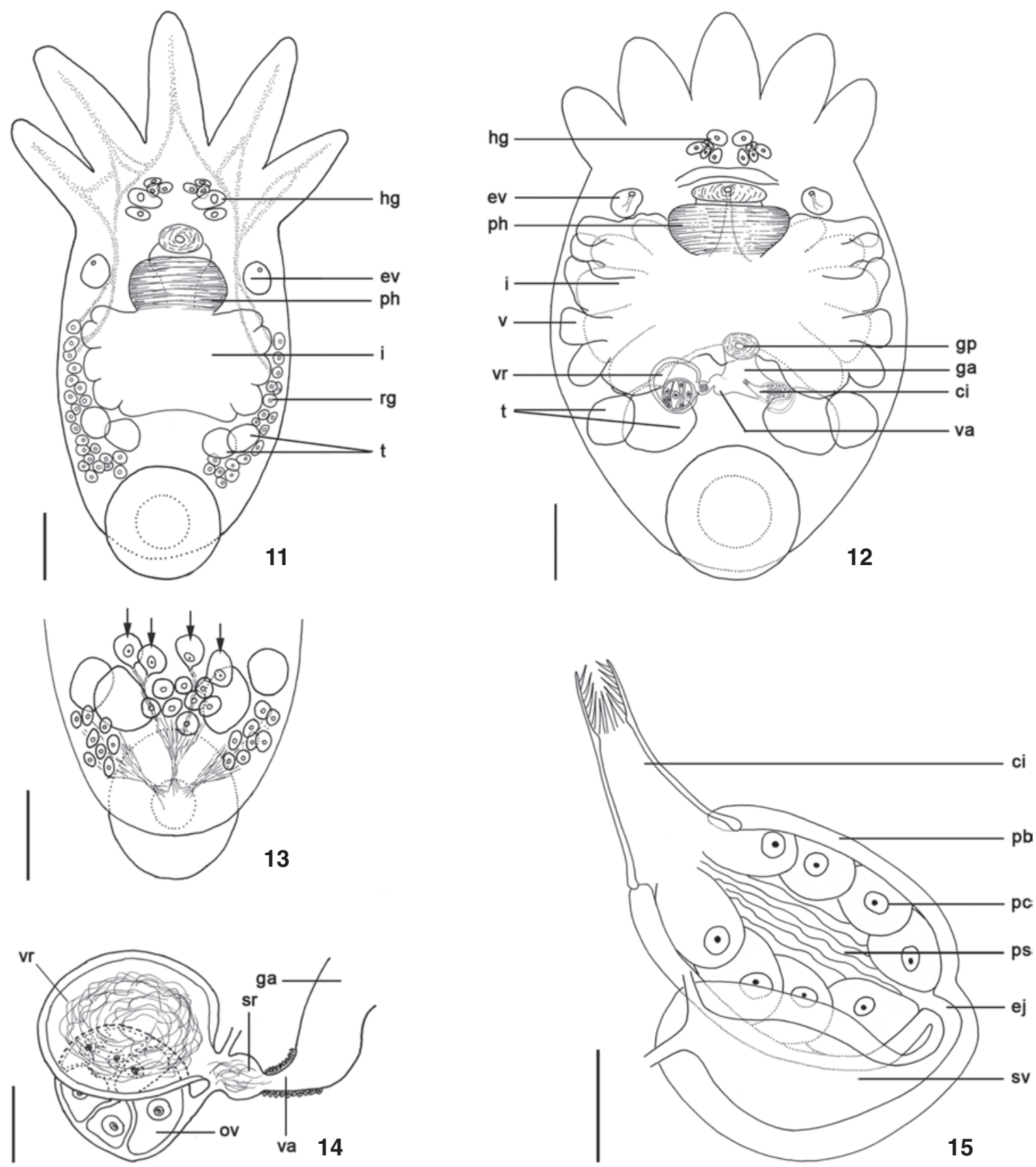

Figures 11-15. Temnocephala minutocirrus sp. nov.: (11) juvenile, ventral view, showing rhabditogenic glands (rg) extending along sides of intestinal sac (i), still uncovered by vitellarium, and its ducts entering tentacles, pharynx (ph), excretory vesicles (ev), testes (t), and Haswell glands (hg), bar = $100 \mu \mathrm{m}$; (12) incomplete diagram of adult specimen killed with cold AFA and slight cover slip pressure showing vesicula resorbens (vr), intestinal sac (i), vagina (va), cirrus (ci), genital atrium (ga) leading to genital pore (gp), vitellarium (v), pharynx (ph), excretory vesicles (ev), testes (t), and Haswell glands (hg), bar $=200 \mu \mathrm{m}$; (13) dorsal view showing posterolateral disk glands and the two pairs of large disk glands (paranephrocytes?)(arrows), bar $=100 \mu \mathrm{m}$; (14) female reproductive complex, showing ovary (ov) seminal receptacle vesicula intermedia (sr), vagina (va), genital atrium (ga), and vesicula resorbens (vr), bar = 50 $\mu \mathrm{m}$; $(15)$ prostatic bulb receiving, apically, ejaculatory duct (ej), prostatic cells ( $p c)$, prostatic secretion (ps), prostatic bulb muscular wall (pb), cirrus (ci), and seminal vesicle (sv), bar $=25 \mu \mathrm{m}$. 


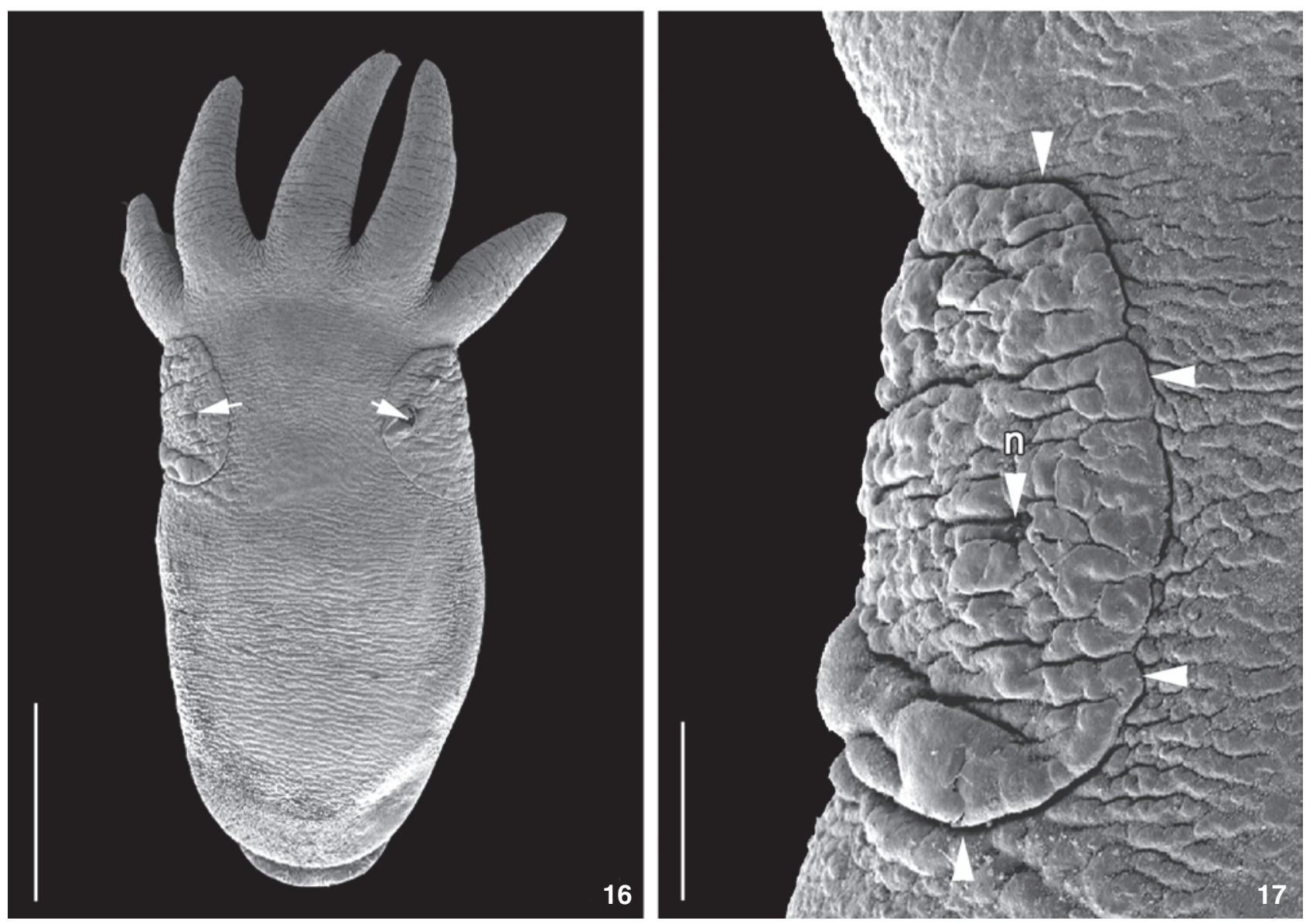

Figures 16-17. Temnocephala minutocirrus sp. nov. (SEM): (16) adult, dorsal view, showing dorsolateral 'excretory' syncytial plates and nephridiopores (arrows), bar $=250 \mu \mathrm{m}$; (17) higher magnification of left syncytial plate, showing off-center nephridiopore ( $\mathrm{n}$ ), and the clear limits of the plate (white head arrows) and highly corrugated surface, bar $=50 \mu \mathrm{m}$.

complex, forming two, lateral bunches extending from the end of the intestinal sac to anterior border of the adhesive disc (Figs 9 and 13), including two pairs, of large, round, more central cells (paranephrocytes?), just ahead of testes, 35-73 (48, n = 10, 11) (Fig. 9, black head arrows) and (Fig. 11, black arrows).

Reproductive system. Female. Gonopore between middle and posterior thirds of body (Fig. 12); ovary round, 27-87 (68, n $=11,17)$ long, 42-127 (90, $\mathrm{n}=11,27)$ wide (Fig. 14); seminal receptacle is just a dilation of the duct, forming a 'vesicula intermedia'; vitellarium arborescent, extending laterally beyond the limits of intestinal sac, touching sides of body (Figs 6 and 12); genital atrium spacious, elongate, vagina $25-75(41,15)$ long (Fig. 14), with weak muscular wall, without muscular sphincters; vesicula resorbens (Fig. 14), with thick wall, 62-160 (105, $30)$ long, 77-162 $(118,30)$ wide, and vitellarium over intestinal sac. Eggs with medium size peduncles (Fig. 5), were found ventrally, fixed on coxae, trochanters, and sternum, between middle and hind pair of legs and also dorsally, on scutellum, clavus, and hemelytra (Figs 2 and 4, adult, macropterous females and figure $3,4^{\text {th }}$ instar female nymph) (Fig. 1, adult, macropterous male), 330-360 (349, $\mathrm{n}=8,11)$ long, 180-200 (189, $\mathrm{n}=8,9)$ wide; peduncles 30-120 (72, $\mathrm{n}=8,29)$ long; filament sub-apical. Male. Testes four, aligned in same zone, anterior smaller than posterior, round to oval, sometimes partially superposed; right anterior testis 62-145 $(102, \mathrm{n}=11,26)$ long, 52-162 (115, $\mathrm{n}=11,33)$ wide; right posterior testis $82-172(136, \mathrm{n}=11,30)$ long, 87-212 (156, $\mathrm{n}=11,39)$ wide; left anterior testis 52-150 $(102,27)$ long, $52-137(100,23)$ wide; left posterior testis 82 $187(136,35)$ long, $72-225(154,39)$ wide; both deferent vessels uniting to form large, pyriform, thick-walled, seminal vesicle, 42-82 $(61,12)$ long, 25-45 $(35,5)$ wide; prostatic bulb (Fig. 15) with thick, muscular wall, 47-95 $(67,15)$ long, 27-62 $(46,10)$ wide; cirrus small, slightly curved, 54-76 $(68, \mathrm{n}=5,9)$ long, shaft short, 31-50 $(43, \mathrm{n}=5,8)$ long, shaft base 18-30 $(27, \mathrm{n}=5,5)$ wide (Figs 15, 18-20, and 22); introvert proportionally long, corresponding to $37 \%$ the total size of cirrus (Figs

Revista Brasileira de Zoologia 24 (4): 1043-1051, dezembro 2007 

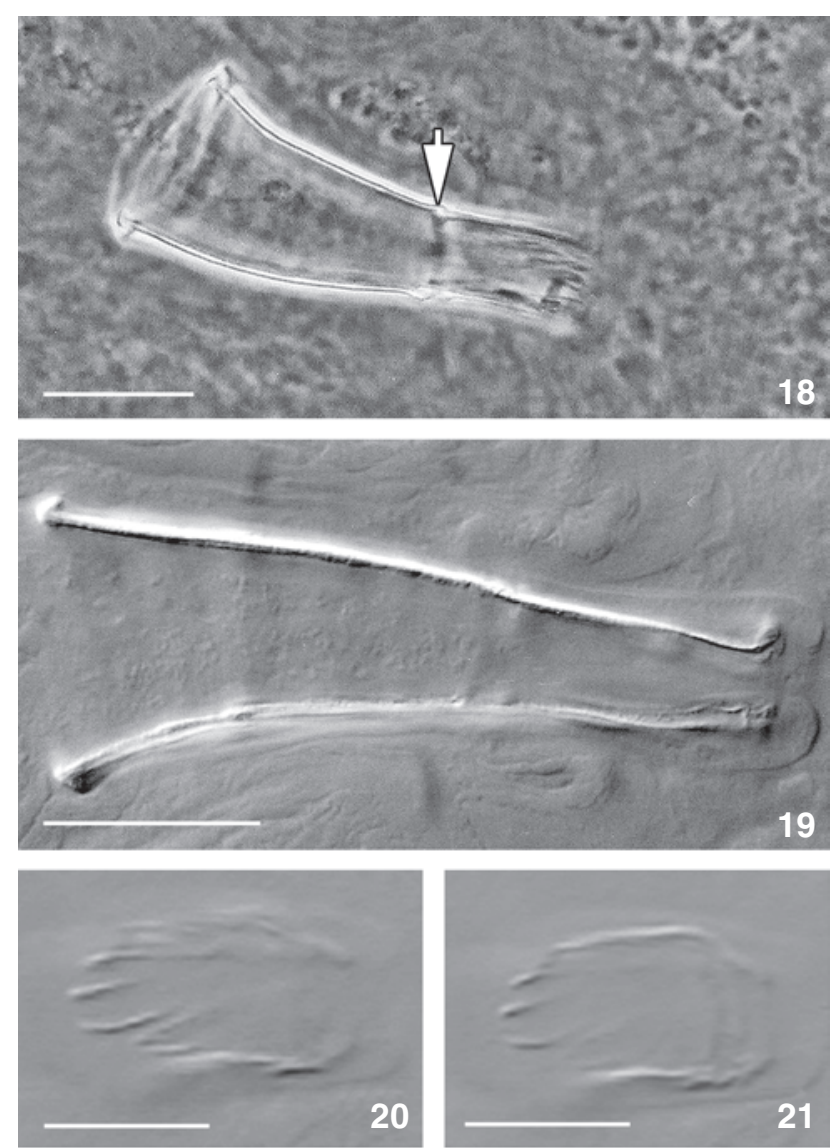

Figures 18-21. Temnocephala minutocirrus sp. nov., photomicrographs of cirri: (18) seen with phase contrast (arrow indicates the proximal limit of introvert), bar $=25 \mu \mathrm{m}$; (19) seen with Nomarski's DIC microscopy, bar $=25 \mu \mathrm{m}$; (20-21) spines of introvert seen with Nomarski's DIC microscopy, in two different focusing planes, bars $=10 \mu \mathrm{m}$; (22-23) line drawing diagram of cirri: (22) cirrus of $T$. minutocirrus sp. nov., bar $=25 \mu \mathrm{m}$; (23) cirrus of $T$. lanei, redrawn from PereirA \& CuOColo (1941, fig. 16), bar $=25 \mu \mathrm{m}$.

19-21), 22-29 (25, $\mathrm{n}=5,3)$ long, $7-13(10, \mathrm{n}=5,2)$ wide at base; maximum introvert width at level of swelling, 11-15 (13, $\mathrm{n}=5,1)$. Introvert's swelling with approximately 12 longitudinal rows of long, thick spines and approximately 6 spines per row (Figs 20-22). Proximal limit of introvert marked with a narrowing of the lumen's diameter, seen from the side as two fine spikes (Fig 18, arrow). Base of cirrus shaft with thick borders in adult specimens (as growth of cirrus starts from distal extremity) showing growth is finished (Figs 18-19 and 22). Ratio between the maximum width of shaft's base/ total length of cirrus 2.6:1; ratio between the total length of introvert/ total length of cirrus 2.7:1.

Type host. Cryphocricos granulosus De Carlo, 1967.

Site. Juvenile and adults on the ventral side of body. Eggs deposited on ventral side of body, between coxae, trochanters, and sternum; on dorsal side on top of scutellum, clavus, and hemelytra.

Type locality. Arroio Forqueta, District of Barra do Ouro,
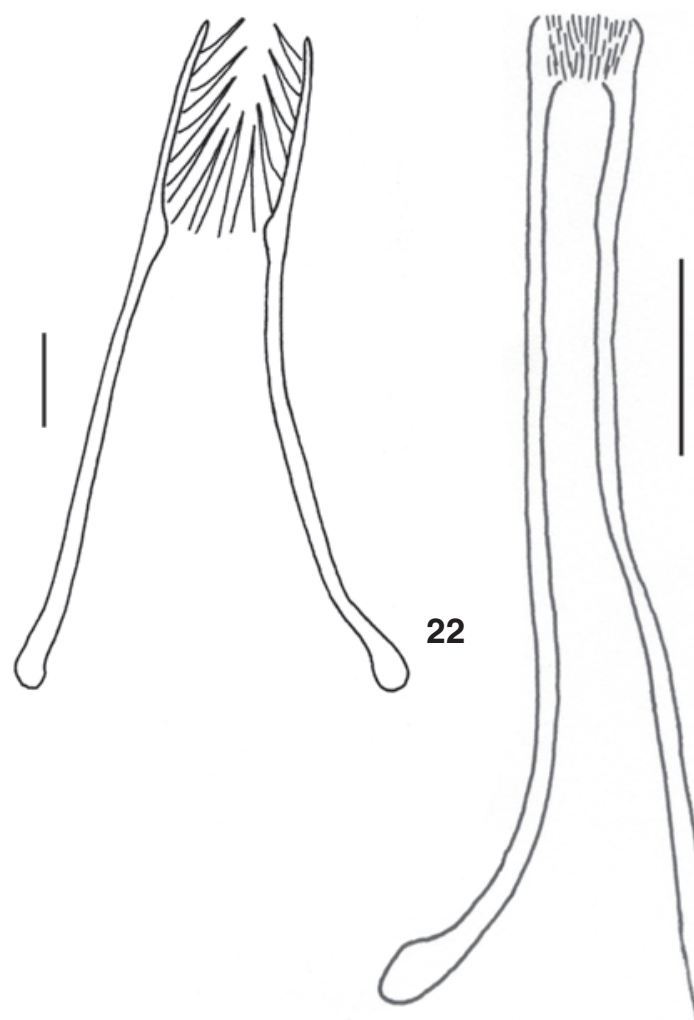

23

Municipality of Maquiné, Rio Grande do Sul, Brazil (29²'19"S, $\left.050^{\circ} 14^{\prime} 47^{\prime \prime} \mathrm{W}\right)$.

Other localities. Arroio Garapiá, District of Barra do Ouro, Municipality of Maquiné, Rio Grande do Sul (29³0'23"S, $050^{\circ} 14^{\prime} 38^{\prime \prime}$ ) and Rio da Divisa, Municipality of São José dos Ausentes, Rio Grande do Sul, Brazil (28³8'17"S, 04957'46”W).

Overall prevalence. $33.02 \%$.

Intensity of infestation. Ranging from 1 to 11 worms/ host. The largest intensities $(5,6,7$, and 11$)$ occurred in seven hosts, all adults.

Helminth specimens deposited. CHIOC $\mathrm{N}^{\circ} 36.877 \mathrm{a}-$ (SBA2548-1-2) holotype fixed in AFA; CHIOC No $36.877 \mathrm{~b}-(\mathrm{SBA}-$ 2548-1-1) paratype fixed in AFA; CHIOC No 36.878 - (SBA-25181-3) paratype fixed in HF; CHIOC No 36.879 - (SBA-1927-1-1) juvenile paratype fixed in AFA; CHIOC No 36.880 - (SBA-20241-1) paratype fixed in SN; CHIOC No 36.881 - (SBA-1929-1-2) cirrus from paratype, in deF; CHIOC No 36.882 - (SBA-2600-2-16) unhatched eggs. 
Host specimens deposited. Seventeen specimens of $C$. granulosus were deposited in the Colorado Entomological Institute; 14 specimens were deposited in the Coleção do Departamento de Zoologia, Laboratório de Entomologia Sistemática, Universidade Federal do Rio Grande do Sul (DZRS/UFRGS); the remaining specimens in the Coleção do Laboratório de Helmintologia (SBA), Departamento de Zoologia, UFRGS.

Etymology. (L. minutocirrus: minutus = minute, small + cirrus: a substantive). Temnocephala minutocirrus sp. nov. The specific epithet minutocirrus was given because the cirrus in this species is very small, being the smallest cirrus among the species of Temnocephala previously studied.

Remarks. The shape and localization of the DLSPs are unique to this new species, with a characteristic corrugated surface which can be seen with SEM (Figs 16 and 17), and even before fixation of any kind. Pigmentation in this species is lacking, even though their hemipteran hosts do not have any orifices in which the temnocephalans can retreat during the occasion of several ecdyses. Unlike the other previously described species of Temnocephala from hemipterans, T. curvicirri show dark body pigmentation when alive, assuring an excellent mimicry with the host's color. The testes usually are in the same zone, being the anterior pair smaller than the posterior pair. This is the first time that eggs were found on the dorsal surface of the host. Temnocephala curvicirri from Belostoma spp. was never found to lay eggs on the dorsal side of the host. The finding of eggs, juvenile, and adult temnocephalans on $4^{\text {th }}$ instar nymphs, even if in low prevalence, is also reported for the first time, maybe due to the several ecdyses that these insects undergo. The infrapopulations living on nymphs are usually lost after each ecdysis. The largest intensities (5, 6, 7, and 11) occurred in seven hosts, all adults, i.e., specimens that will not undergo further ecdyses, while infrapopulations made of 1 and 2 specimens were the most commonly found.

\section{DISCUSSION}

Temnocephala minutocirrus sp. nov. is described from southern Brazil, as an ectosymbiont on creeping water bugs ( $4^{\text {th }}$ instar nymphs, and brachypterous and macropterous adults). This is the second time that naucorids have been recorded as hosts of temnocephalans. Vianna \& DE Melo (2002), heteropterologists, described in detail hemipterans and physical characteristics of streams from which the insects were collected during a large survey of aquatic heteropterans in the State of Minas Gerais, Brazil. These authors did not provide descriptions and/or measurements of the 29 juvenile and the 12 adult temnocephalan specimens found, nor present illustrations (drawings or photomicrographs), which could demonstrate that the specimens found on naucorids and nepids, were conspecific with those described from trichodactylid brachyuran crabs, Trichodactylus sp., from the State of São Paulo by Pereira \& Cuocolo (1941, Figs 14-16), as T. lanei.

Vianna \& de Melo (2002) quoting Pereira \& Cuocolo (1941) wrote: "penis morphology as a short conical structure with a slight quitinous thorn crown at its distal end", as the reason why they gave the same name, T. lanei, which had been used only at the time of the original description by Pereira \& CuOColo (1941) to identify their specimens from trichodactylid crabs.

The cirrus of T. minutocirrus sp. nov. has the smallest shaft among the known species of the genus, while the introvert spines are long. Comparing the cirrus' length of $T$. lanei, the smallest cirrus known to date, with that of T. minutocirrus sp. nov. the latter has the cirrus $50 \%$ smaller $(0.12 \mathrm{~mm}-T$. lanei and $0.07 \mathrm{~mm}-T$. minutocirrus sp. nov.). The original drawing made by Pereira \& CuOcolo (1941), presented as figure 23 in the present work, side-by-side with the cirrus of the new species, shows that the differences are not restricted to size but also to shape. The difference in shape can be further appreciated by looking at the photomicrographs in figures 18 and 19 .

Several attempts were made to borrow the specimens of Vianna \& DE Melo (2002), indirectly (correspondence to the Department of Parasitology of the UFMG) and directly to Dr Alan L. de Melo, but neither attempt was successful. Dr de Melo could not make any specimens available to us at that time because all specimens had been sent out for identification by $\mathrm{Dr}$ Walter Dioni in Mexico (pers. comm. by Dr Alan L. de Melo). The efforts to examine the type specimens of T. lanei were also unsuccessful. Specimens were not found in the collection of the Laboratório de Parasitologia Animal, Instituto Biológico of São Paulo where Pereira \& Cuocolo worked (pers. com. by the Curator of the Laboratório de Parasitologia Animal, Dr Suely Moda de Oliveira). Pereira \& Cuocolo (1941) did not indicate the institution where their type specimens were deposited, so, at present, the specimens are unaccounted for in Brazil, including the type specimens of T. lanei. Temnocephalan specimens should also be collected and treated accordingly, from Trichodactylus sp. at the type locality, Fazenda Poço Grande, Juquiá, State of São Paulo. Additionally, T. lanei needs to be properly described, have the correct host species determined, i.e. the species of Trichodactylus determined, and representative specimens deposited in a public collection of crustaceans.

\section{ACKNOWLEDGEMENTS}

To CNPq for partial financial support through the grant (47-4223/2004-3), to the senior author; Abner Chiquieri, Departamento de Línguas, Universidade Federal Rural do Rio de Janeiro, Seropédica, Rio de Janeiro, for his advice on the correct formation of the specific name of the new species; Fábio Villela, for the collection of many specimens of $C$. granulosus and valuable field information about the habitats in the tributary creeks of Rio Maquiné; Adriano Sanches Melo and Marlon Vasconcelos, Departamento de Ecologia, UFRGS for valuable information about the collection locations and loan of the Surber sampler; Dely Noronha, Curator, Instituto Oswaldo Cruz, Rio de Janeiro, for accepting type specimens for deposit in the CHIOC; John Polhemus, for the identification of the hosts and for receiving specimens to be deposited in the Colorado Entomological Insti-

Revista Brasileira de Zoologia 24 (4): 1043-1051, dezembro 2007 
tute collection; Philip J. Scholl for reviewing the English version of the manuscript; Danilo K. de Calazans, Laboratório de Crustáceos, Fundação Universidade do Rio Grande (FURG), for allowing us to use the Olympus BX50 microscope; Jocélia Grazia for the valuable discussions on the external morphology and anatomy of hemipterans and for accepting naucorids for deposit in the UFRGS collection; Luiz C.C. Daudt and Laura P. Utz for helping with field collections; Suely Moda de Oliveira, Curator of the Coleção do Laboratório de Parasitologia Animal, Instituto Biológico de São Paulo, for the valuable information on the whereabouts of the Pereira and Cuocolo's specimens of T. lanei; Centro de Microscopia Eletrônica (CME), UFRGS; Programa de PósGraduação em Biologia Animal (PPG-BAN), Departamento de Zoologia, Universidade Federal do Rio Grande do Sul.

\section{REFERENCES}

Amato, J.F.R. \& S.B. Aмато. 2005. New species of Temnocephala Blanchard (Platyhelminthes, Temnocephalida) ectosymbiont on giant water bugs, Belostoma spp. (Hemiptera, Belostomatidae) from southern Brazil. Revista Brasileira de Zoologia 22 (1): 107-118.

Амato, J.F.R.; S.B. Амato \& S.A. Seixas. 2005. Temnocephala lutzi Monticelli (Platyhelminthes, Temnocephalida) ectosymbiont on two species of Trichodactylus Latreille (Crustacea, Decapoda, Trichodactylidae) from southern Brazil. Revista Brasilei- ra de Zoologia 22 (4): 1085-1094.

Amato, J.F.R.; S.B. Амato \& S.A. Seixas. 2006. A new species of Temnocephala Blanchard (Platyhelminthes, Temnocephalida) ectosymbiont on Trichodactylus fluviatilis Latreille (Crustacea, Decapoda, Trichodactylidae) from southern Brazil. Revista Brasileira de Zoologia 23 (3): 796-806.

Cannon, L.R.G. \& K.B. Sewell. 1995. Craspedellinae Baer, 1931 (Platyhelminthes: Temnocephalida) ectosymbionts from the branchial chamber of Australian crayfish (Crustacea: Parastacidae). Memoirs of the Queensland Museum 38: 397-418.

Damborenea, M.C. \& L.R.G. Cannon. 2001. On neotropical Temnocephala (Platyhelminthes). Journal of Natural History 35: 1103-1118.

Joffe, B.I.; I.V. Solove \& L.R.G. CAnNon. 1995. The structure of the epidermis in Didymorchis (Temnocephalida: Platyhelminthes). Australian Journal of Zoology 43: 631-641.

Pereira, C. \& R. Cuocolo. 1941. Estudos sobre "Temnocephalidae Monticelli, 1899", com estabelecimento de dois novos gêneros australianos e descrição de duas novas espécies neotrópicas. Arquivos do Instituto Biológico 12 (9): 101-127.

RomeIs, B. 1968. Taschenbuch der Microskopischen Technik. 16. Munchen, Aufl. Oldenbourg, XIV+695p.

Vianna, G.J.C. \& A.L. De Melo. 2002. Aquatic Heteroptera as host of Temnocephala Blanchard (Platyhelminthes: Temnocephalidae) in Minas Gerais, Brazil. Lundiana 3: 151-153.

Received in 23.IV.2007; accepted in 20.XI.2007. 